\title{
The effect of interleukin-13 (IL-13) and interferon- $\gamma$ (IFN- $\gamma$ ) on expression of surfactant proteins in adult human alveolar type II cells in vitro
}

\author{
Yoko Ito ${ }^{*}$, Robert J Mason
}

\begin{abstract}
Background: Surfactant proteins are produced predominantly by alveolar type II (ATII) cells, and the expression of these proteins can be altered by cytokines and growth factors. Th1/Th2 cytokine imbalance is suggested to be important in the pathogenesis of several adult lung diseases. Recently, we developed a culture system for maintaining differentiated adult human ATII cells. Therefore, we sought to determine the effects of IL-13 and IFN- $\gamma$ on the expression of surfactant proteins in adult human ATIl cells in vitro. Additional studies were done with rat ATIl cells.

Methods: Adult human ATIl cells were isolated from deidentified organ donors whose lungs were not suitable for transplantation and donated for medical research. The cells were cultured on a mixture of Matrigel and rat-tail collagen for $8 \mathrm{~d}$ with differentiation factors and human recombinant IL-13 or IFN- $\gamma$.

Results: IL-13 reduced the mRNA and protein levels of surfactant protein (SP)-C, whereas IFN- $\gamma$ increased the mRNA level of SP-C and proSP-C protein but not mature SP-C. Neither cytokine changed the mRNA level of SP-B but IFN- $\gamma$ slightly decreased mature SP-B. IFN- $\gamma$ reduced the level of the active form of cathepsin H. IL-13 also reduced the mRNA and protein levels of SP-D, whereas IFN- $\gamma$ increased both mRNA and protein levels of SP-D. IL-13 did not alter SP-A, but IFN- $\gamma$ slightly increased the mRNA levels of SP-A.

Conclusions: We demonstrated that IL-13 and IFN- $\gamma$ altered the expression of surfactant proteins in human adult ATII cells in vitro. IL-13 decreased SP-C and SP-D in human ATII cells, whereas IFN- $\gamma$ had the opposite effect. The protein levels of mature SP-B were decreased by IFN- $\gamma$ treatment, likely due to the reduction in active form cathpesin $\mathrm{H}$. Similarly, the active form of cathepsin $\mathrm{H}$ was relatively insufficient to fully process proSP-C as IFN- $\gamma$ increased the mRNA levels for SP-C and proSP-C protein, but there was no increase in mature SP-C. These observations suggest that in disease states with an overexpression of IL-13, there would be some deficiency in mature SP-C and SP-D. In disease states with an excess of IFN- $\gamma$ or therapy with IFN- $\gamma$, these data suggest that there might be incomplete processing of SP-B and SP-C.
\end{abstract}

\section{Background}

The alveolar type II (ATII) cell produces pulmonary surfactant and most of the surfactant proteins in the lung. The four surfactant proteins, SP-A, SP-B, SP-C and SP$\mathrm{D}$, have been shown to play pivotal roles in the regulation of surfactant lipid metabolism, lipid membrane organization and host defense in the lung [1]. Dysregulation of surfactant protein expression has been

\footnotetext{
* Correspondence: itoy@njhealth.org

* Correspondence: itoy@njhealth.org Denver, CO 80206, USA
}

(c) 2010 Ito and Mason; licensee BioMed Central Ltd. This is an Open Access article distributed under the terms of the Creative Commons Attribution License (http://creativecommons.org/licenses/by/2.0), which permits unrestricted use, distribution, and reproduction in any medium, provided the original work is properly cited. likely have impor $[2-7]$. Alterations in these proteins homeostasis and defense against pathogens.

SP-A and SP-D are water-soluble and belong to the collectin subgroup of C-type lectins [8]. SP-A genetic variants are predisposed to both interstitial pulmonary fibrosis (IPF) and lung cancer [2,3]. SP-A-/- mice show increased susceptibility to bacterial, viral and fungal pathogens but have no reported lung structural abnormalities [9]. SP-D-/- mice spontaneously develop emphysema and fibrosis, which is thought to be the result of 
sustained inflammation associated with abnormal oxidant metabolism and matrix metalloproteinase (MMP) activity [10]. Both SP-A and SP-D knockout mice have increased lung inflammation when they are infected with bacteria or viruses compared to wild-type strains [11]. SP-A and/or SP-D concentration in bronchoalveolar lavage fluid (BALF) are significantly decreased in patients with acute respiratory distress syndrome (ARDS), IPF, collagen vascular disease associated interstitial pneumonia, hypersensitivity pneumonia, sarcoidosis and cystic fibrosis [12-15]. Van De Graaf et al. found that SP-A is decreased in BALF from patients with bronchial asthma [16], whereas Cheng, G. et al. reported increased amounts of SP-A in both bronchial and alveolar lavage and increased levels of SP-D in alveolar lavage fluid but not bronchial lavage fluid in patients with asthma [17]. Cigarette smoking is reported to reduce SP-A and SP-D levels in BALF $[18,19]$. Although SP-A and SP-D are thought to be important components in innate immunity, there has not been an association of genetic deficiencies of SP-A or SP-D in humans with recurrent or persistent respiratory infections.

SP-B and SP-C are extremely hydrophobic and play critical roles in the biophysical functions of surfactant [20]. Polymorphisms of the SP-B gene are reported to be associated with squamous cell carcinoma of lung [4], risk for acute respiratory distress syndrome (ARDS) [5] and chronic obstructive pulmonary disease (COPD) [6]. Recent studies have revealed that some familial forms of pulmonary fibrosis are associated with mutations in the SP-C gene [7]. Depending on the genetic background, SP-C deficient mice can spontaneously develop chronic inflammation and have increased and prolonged pulmonary fibrosis following intratracheal instillation of bleomycin [21].

IL-13 is a pleiotropic cytokine and a major effector molecule at sites of Th2 inflammation and tissue remodeling. IL-13 is a potent stimulator of eosinophilic, lymphocytic, and macrophage-dominant inflammation, mucus metaplasia, and fibrosis. [22-27]. IL-13 dysregulation plays an important role in the pathogenesis of a variety of lung diseases including asthma, IPF, viral pneumonia, and COPD [22,28-33]. In addition, BALF from IL-13 overexpressing mice have a 3- to 6-fold increase in surfactant phospholipids, a 2- to 3-fold increase in SP-A, $-\mathrm{B}$, and $-\mathrm{C}$, and a 70-fold increase in SP-D [34]. In neonatal rat ATII cells, IL-4 and IL-13, but not IFN- $\gamma$, increases intracellular SP-D, but levels of other surfactant proteins were not reported [35].

IFN- $\gamma$ is the prototypic Th1 cytokine and is known to play a key role in the regulation of diverse immune responses [36]. Dysregulated IFN- $\gamma$ production has been implicated in a large number of diseases, which are related to inflammation and remodeling characterized by tissue atrophy and/or destruction [37]. In pulmonary emphysema, alveolar septal destruction is accompanied by increased numbers of $\mathrm{CD} 8+$ cells that produce IFN- $\gamma$ and IFN- $\gamma$ inducible protein 10/CXCL10 $[38,39]$. Overexpression of IFN- $\gamma$ in mice causes pulmonary emphysema, which is suggested to be due to cathepsin S-dependent epithelial cell apoptosis $[37,40]$. In human fetal alveolar epithelial cells in vitro, IFN- $\gamma$ is reported to increase SP-A protein levels by 3-fold and SP-A mRNA levels by 2.7 -fold but does not alter SP-B and SP-C mRNA levels [41].

Although dysregulation of the Th1/Th2 cytokine is related to the pathogenesis of several adult lung diseases and alterations of surfactant proteins have been reported in variety of lung diseases, the effect of IL-13 or IFN- $\gamma$ on the expression of surfactant proteins in primary adult human ATII cells has not been reported. Methods for isolating and culturing adult rat and mouse ATII cells and fetal human ATII cells have been available for years, but there has been less success in maintaining the differentiated functions of adult human alveolar epithelial cells in primary culture. A variety of methods for isolating human type II cells have been published and some of their properties have been described [42-47], but maintenance of surfactant protein expression in adult human ATII cells in monolayer culture has been difficult. Recently, we developed a system for maintaining the differentiated functions of adult human ATII cells in vitro [48]. Therefore, the aim of this study is to investigate the IL-13 and IFN- $\gamma$ effect on the expression of the surfactant proteins using primary human adult ATII cells in monolayer culture in vitro. The experiments with human ATII cells were also repeated with rat ATII cells.

\section{Methods}

\section{Donor information}

We obtained human lungs from deidentified organ donors whose lungs were not suitable for transplantation and donated for medical research through the National Disease Research Interchange (Philadelphia, PA) and the International Institute for the Advancement of Medicine (Edison, NJ). The Committee for the Protection of Human Subjects at National Jewish Health approved this research. We selected donors with reasonable lung function with a PaO2/FIO2 ratio of $>250$, no history of clinical lung disease and a chest radiograph that did not indicate infection, and a limited time on the ventilator. The gender, age, and smoking history were variable and not selection criteria. The human donors used in this study included 6 males and 6 females with age ranges from 10 to 72, and there were 7 current smokers and 5 nonsmokers. Hence, there was a significant amount of variability among the donors, as expected. 


\section{Human ATIl cell isolation}

We modified the human type II cell isolation method published by Fang and coworkers [44]. Briefly, the middle lobe was perfused, lavaged, and then instilled with elastase (12.9 U/ml; Roche Diagnostics, Indianapolis, IN) for 50 minutes at $37^{\circ} \mathrm{C}$. The lung was minced, and the cells were isolated by filtration and partially purified by centrifugation on a discontinuous density gradient made of Optiprep (Accurate Chemical Scientific Corp., Westbury, NY) with densities of 1.080 and 1.040, and by negative selection with CD14-coated magnetic beads (Dynal Biotech ASA, Oslo, Norway) and binding to IgGcoated Petri dishes (Sigma, St. Louis, MO). The cells were counted and cytocentrifuged. Cell preparations were made to assess cell purity by staining for cytokeratin (CAM 5.2; Dako Cytomation, Carpinteria, CA). The cells were stored in 10\% dimethyl sulfoxide (DMSO) and $90 \%$ fetal bovine serum (FBS) in liquid nitrogen until they were used in these studies.

\section{Culture of human ATII cells}

The isolated cells were resuspended in Dulbecco's Modified Eagle's Medium (DMEM) supplemented with 10\% FBS and $2 \mathrm{mM}$ glutamine, $2.5 \mu \mathrm{g} / \mathrm{ml}$ amphotericin $\mathrm{B}$, $100 \mu \mathrm{g} / \mathrm{ml}$ streptomycin, 100 units $/ \mathrm{ml}$ penicillin $\mathrm{G}$ (Mediatech, Inc., Manassas, VA), and $10 \mu \mathrm{g} / \mathrm{ml}$ gentamicin (Sigma-Aldrich, St. Louis, MO). 4.0 million cells were plated on $4.2 \mathrm{~cm}^{2}$ millicell inserts (Millipore Corp., Bedford, MA) that had been previously coated with a mixture of $50 \%$ Matrigel (BD Biosciences, Bedford, MA) and $50 \%$ rat-tail collagen in DMEM with $10 \%$ FBS [49]. For most of our studies, after $48 \mathrm{~h}$ the media was changed to DMEM including 5\% heat inactivated human serum (Mediatech, Inc.) and $10 \mathrm{ng} / \mathrm{ml}$ TGF $($ R\&D Systems, Minneapolis, MN). Two days later, $10 \mathrm{ng} / \mathrm{ml}$ keratinocyte growth factor (KGF, Amgen, Thousand Oaks, CA) was added instead of TGF $\alpha$ for $4 \mathrm{~d}$, and the medium was changed every other day. Therefore, cells in all conditions were cultured for a total of $8 \mathrm{~d}$ with or without human recombinant IL-13 or IFN- $\gamma$ (R\&D Systems) added for the last 2, 4 or $6 \mathrm{~d}$. Additional studies were done with a slightly different set of differentiation factors: $\mathrm{KGF}(\mathrm{K})$, isomethylbutyl xanthene (I) and $8 \mathrm{Br}$ cAMP (A) for $2 \mathrm{~d}$ followed by KIA and dexamethasone (D) for $4 \mathrm{~d}$, designated as KIAD [48].

\section{Rat ATII cell isolation and culture}

ATII cells were isolated from pathogen-free adult male Sprague-Dawley rats (Harlan, Indianapolis, IN) by dissociation with porcine pancreatic elastase (Roche Diagnostics) and partial purification on discontinuous density gradients by methods previously described [50]. This research was approved by the Animal Care Committee at National Jewish Health (IACUC). Type II cells were plated on $4.2 \mathrm{~cm}^{2}$ millicell inserts (Millipore Corp). 2.5 million freshly isolated viable type II cells were plated in DMEM containing 5\% rat serum (RS) (Pel-Freez Biologicals, Rogers, AR), $2 \mathrm{mM}$ glutamine, $2.5 \mu \mathrm{g} / \mathrm{ml}$ amphotericin $\mathrm{B}, 100 \mathrm{\mu g} / \mathrm{ml}$ streptomycin, $100 \mathrm{units} / \mathrm{ml}$ penicillin $\mathrm{G}$ (all from Mediatech, Inc.), and $10 \mu \mathrm{g} / \mathrm{ml}$ gentamicin (Sigma-Aldrich). After attachment for $24 \mathrm{~h}$, the cells were rinsed twice with DMEM and then cultured in DMEM containing RS, glutamine, antibiotics described above and $10 \mathrm{ng} / \mathrm{ml} \mathrm{KGF}$ for $6 \mathrm{~d}$ with or without recombinant rat IL-13 $(20 \mathrm{ng} / \mathrm{ml})$ or rat IFN- $\gamma$ $(100 \mathrm{ng} / \mathrm{ml})$ (R\&D Systems) for the last $4 \mathrm{~d}$.

\section{Immunoblotting and real-time PCR (RT-PCR)}

Protein and mRNA expression of corresponding genes were measured by western blotting and real-time RTPCR according to protocols as described previously [49]. Polyacrylamide gradient gels (8-16\%; Invitrogen Corporation) run in tris glycine buffer were used to separate proteins. Proteins were run in the reduced state except for mature SP-B, which was run unreduced. For western blotting, protein loading was normalized to glyceraldehyde-3-phosphate dehydrogenase (GAPDH). The primary antibodies were mouse anti-human SP-A (PE-10), SP-D (1G11) (a gift from Yoshio Kuroki), rabbit anti-rat SP-A and SP-D, rabbit anti-human proSP-B, rabbit anti-sheep mature SP-B (Chemicon International, Temecula, CA), rabbit anti-human proSP-C, rabbit antihuman mature SP-C (Seven Hills Bioreagents, Cincinnati, OH), mouse anti-human ABCA3 (Seven Hills Bioreagents), mouse anti-human Cathepsin $\mathrm{H}$, and mouse anti-rabbit GAPDH (abcam, Cambridge, MA). The intensities of the bands were calculated using NIH Image software (version 1.62). For real-time RT-PCR, the expression levels of genes were expressed as a ratio to the expression of the constitutive probe 36B4, acidic ribosomal phosphoprotein P0 [51]. The specific primers and probes used in these experiments are listed in Table 1.

\section{Immunofluorescence of human proSP-C}

The cells were fixed in $4 \%$ paraformaldehyde, and then the filters were embedded in paraffin as described [52]. The primary antibodies included rabbit anti-human proSP-C (Seven Hills Bioreagents). The secondary antibody was donkey Alexa Fluor 488 anti-rabbit IgG $(\mathrm{H}+\mathrm{L})$ from Invitrogen (Corporation, Carlsbad, CA).

\section{Statistical Analysis}

All data were presented as means \pm standard error of the mean. One-way ANOVA was used to compare the difference between two or more groups. Appropriate post hoc tests were selected for multiple comparison. Statistical significance was set at $\mathrm{p}<0.05$. 
Table 1 Sequence of Primer and Probes Used in This Study

\begin{tabular}{llll}
\hline Gene Name & Forward Primer & Probe & Reverse Primer \\
\hline SP-A & GCCATTCAGGAGGCATGTG & CGGCCGCATTGCTGTCCCA & GCCTCATTTCCTCTGGATTCC \\
SP-B & TGGGAGCCGATGACCTATG & CAAGAGTGTGAGGACATCGTCCACATCC & GCCTCCTTGGCCATCTTGT \\
SP-C & CGGGCAAGAAGCTGCTTCT & CCACACCGCAGGGACAAACCCT & CCACACCGCAGGGACAAACCCT \\
SP-D & ACACAGGCTGGTGACAGTTG & CCTCTCCACGCTCTGCCGCGT & TGTTGCAAGGCGGCATT \\
$36 B 4$ & CCACGCTGCTGAACATGCT & AACATCTCCCCCTTCTCCTTTGGCTT & TCGAACACCTGCTGGATGAC \\
\hline
\end{tabular}

Definition of abbreviations: SP, surfactant protein

\section{Results}

Expression of surfactant proteins in adult human ATII cells cultured on Matrigel and rat tail collagen coated inserts with IL-13

Human ATII cells were isolated and cultured in vitro for $8 \mathrm{~d}$ ( $2 \mathrm{~d}$ adherence, $2 \mathrm{~d}$ TGF $\alpha$ and $4 \mathrm{~d}$ KGF) with 2 or $20 \mathrm{ng} / \mathrm{ml}$ human recombinant IL-13. The protein level of mature SP-C showed significant dose-dependent down-regulation by human recombinant IL-13 (Figure 1A, B). Next we used $20 \mathrm{ng} / \mathrm{ml}$ human recombinant IL-13 for a time-course experiment, added it to the cultured cells for the final 2, 4 or $6 \mathrm{~d}$ and evaluated the expression of surfactant protein levels on day 8 by immunoblotting $(n=6)$ (Figure 2A, B). Protein levels of SP-A and mature SP-B were not altered by IL-13, whereas those of mature SP-C and SP-D were greatly down-regulated by 4 or $6 \mathrm{~d}$ of treatment with IL-13 (relative increase of mature SP-C: without IL-13 1.0, $2 \mathrm{~d}$ IL-13 $0.60 \pm 0.13,4 \mathrm{~d}$ IL-13 $0.35 \pm 0.11 \mathrm{p}=0.001,6 \mathrm{~d}$ IL-13 $0.45 \pm 0.19 \mathrm{p}=0.005$; SP-D: without IL-13 1.0, 2 d IL-13 $0.66 \pm 0.12,4$ d IL-13 $0.47 \pm 0.11 \mathrm{p}=0.002,6 \mathrm{~d}$ IL-13 $0.46 \pm 0.17 \mathrm{p}=0.003$ ) (Figure 2A, B).

We then assessed whether IL-13 altered the mRNA levels of surfactant proteins $(n=6)$ (Figure 3A). Consistent with the protein levels (Figure 2B), mRNA levels of SP-C and SP-D were significantly down-regulated in

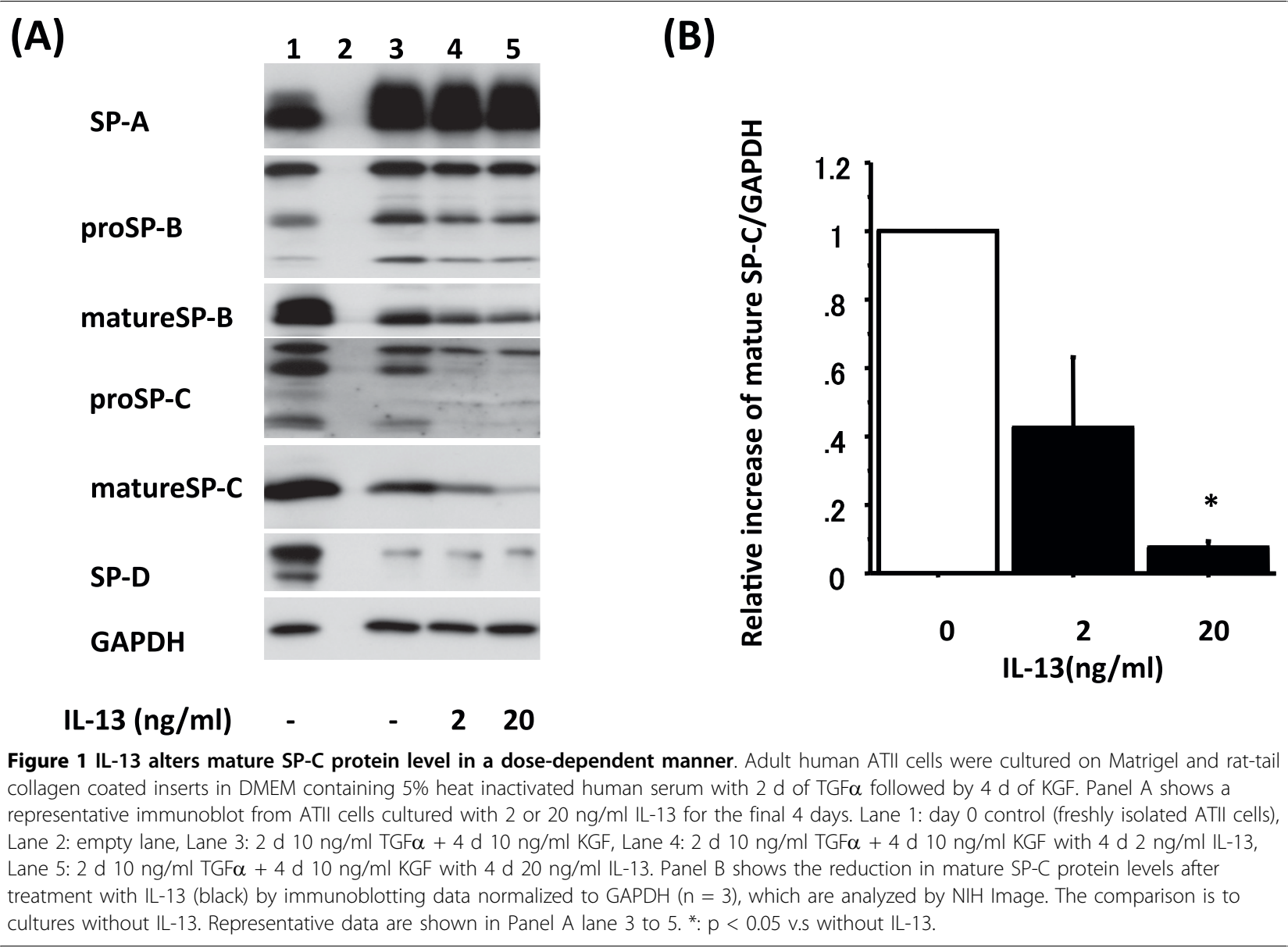



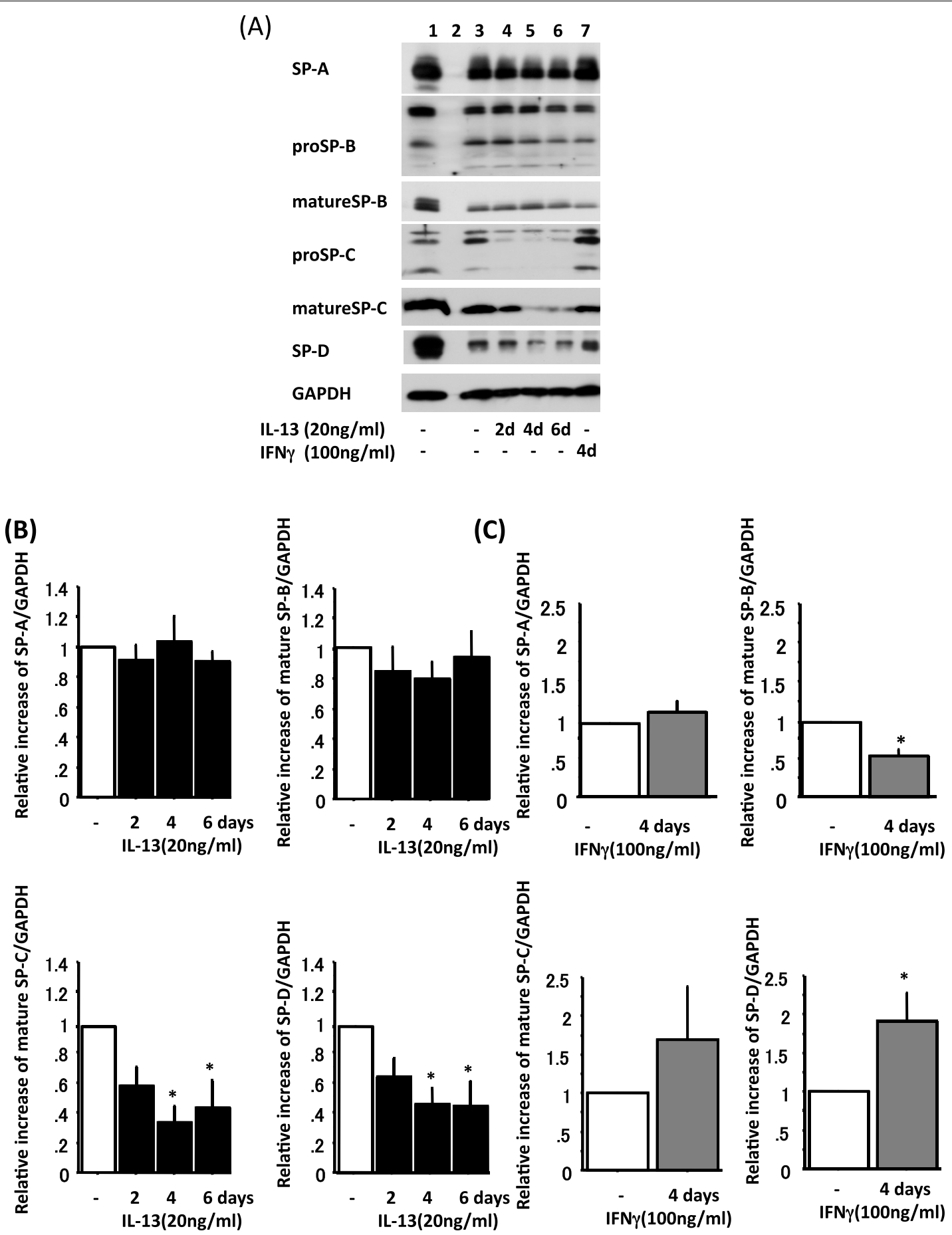

Figure 2 IL-13 and IFN- $\boldsymbol{\gamma}$ alter surfactant protein levels. Adult human ATIl cells were cultured on Matrigel and rat-tail collagen coated inserts in DMEM containing 5\% heat inactivated human serum with $2 \mathrm{~d}$ of TGF $\alpha$ followed by $4 \mathrm{~d}$ of KGF. Panel A shows representative immunoblot

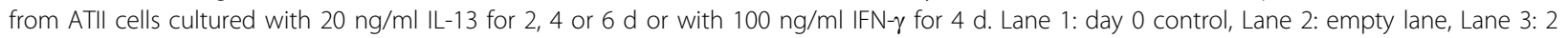
d $10 \mathrm{ng} / \mathrm{ml} \mathrm{TGF} \alpha+4$ d $10 \mathrm{ng} / \mathrm{ml} \mathrm{KGF}$, Lane 4: 2 d $10 \mathrm{ng} / \mathrm{ml} \mathrm{TGF} \alpha+4 \mathrm{~d} 10 \mathrm{ng} / \mathrm{ml} \mathrm{KGF}$ with $2 \mathrm{~d} 20 \mathrm{ng} / \mathrm{ml}$ IL-13, Lane 5: $2 \mathrm{~d} 10 \mathrm{ng} / \mathrm{ml}$ TGF $\alpha+4$ d $10 \mathrm{ng} / \mathrm{ml} \mathrm{KGF}$ with $4 \mathrm{~d} 20 \mathrm{ng} / \mathrm{ml} \mathrm{IL-13,} \mathrm{Lane} 6: 2$ days $10 \mathrm{ng} / \mathrm{ml} \mathrm{TGF} \alpha+4 \mathrm{~d} 10 \mathrm{ng} / \mathrm{ml} \mathrm{KGF}$ with $6 \mathrm{~d} 20 \mathrm{ng} / \mathrm{ml} \mathrm{IL-13,} \mathrm{Lane} \mathrm{7:} 2$ days $10 \mathrm{ng} / \mathrm{ml}$ $\mathrm{TGF} \alpha+4 \mathrm{~d} 10 \mathrm{ng} / \mathrm{ml}$ KGF with $4 \mathrm{~d} 100 \mathrm{ng} / \mathrm{ml} \mathrm{IFN}-\gamma$. Panel B shows surfactant proteins levels from IL-13 (black) time-course treatment immunoblotting data normalized by GAPDH $(n=6)$, which are analyzed by NIH Image. Only SP-A, mature SP-B, mature SP-C and SP-D data are shown. The comparison is to cultures without IL-13. Representative data are shown in Panel A lane 3 to 6. * $^{*} p<0.05$ v.s without IL-13. Panel C shows surfactant proteins levels from IFNy treatment (gray) immunoblotting data normalized by GAPDH $(n=6)$, which are analyzed by $\mathrm{NIH}$ Image. Representative data are shown in Panel A lane 3 and 7. *: $p<0.05$ v.s without IFN- $\gamma$. 


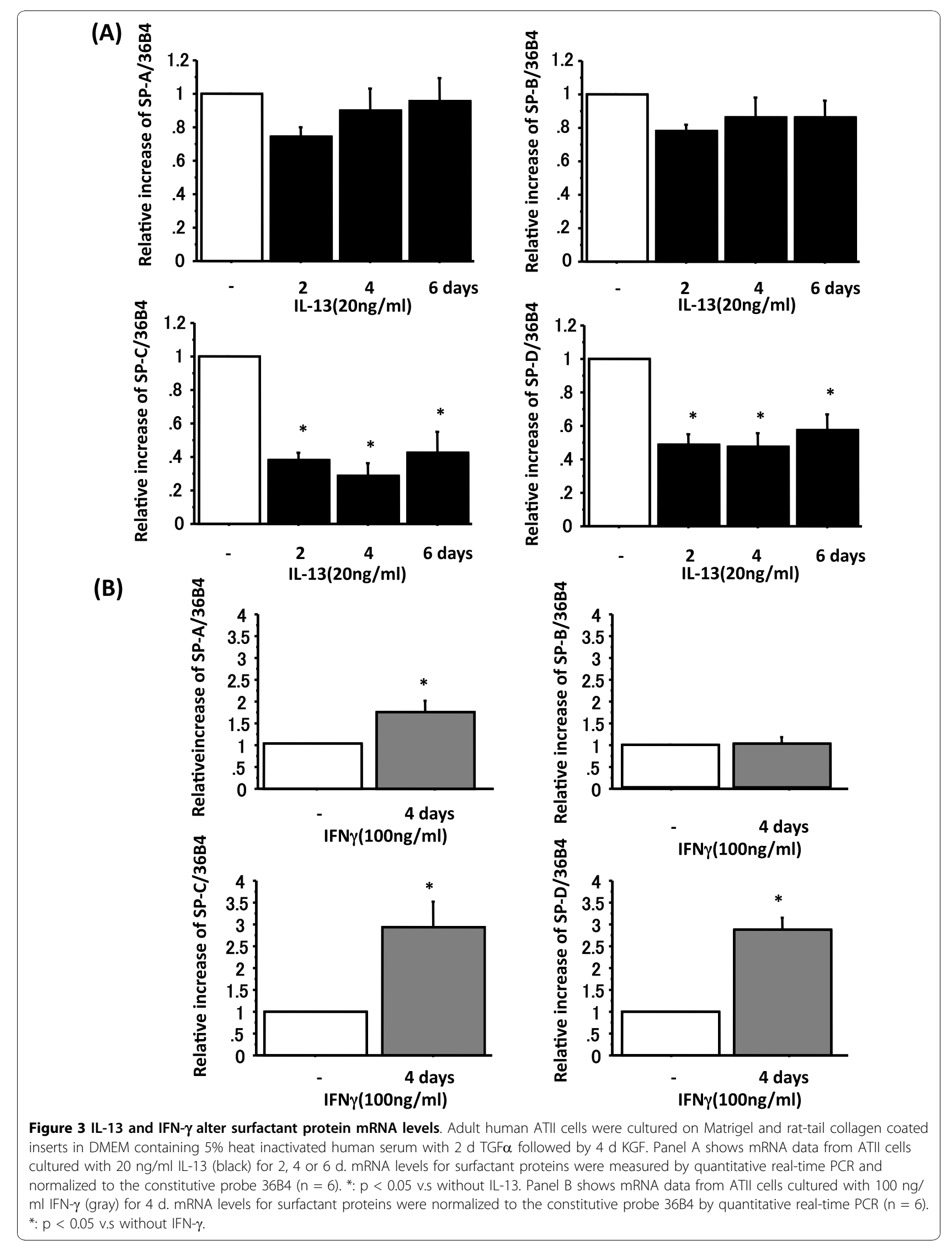


response to 2, 4 or $6 \mathrm{~d}$ of IL-13 treatment (relative increase of SP-C: without IL-13 1.0, 2 d IL-13 $0.38 \pm$ $0.05 \mathrm{p}<0.001,4 \mathrm{~d}$ IL-13 $0.29 \pm 0.07 \mathrm{p}<0.001,6 \mathrm{~d}$ IL-13 $0.42 \pm 0.13 \mathrm{p}<0.001$; SP-D: without IL-13 1.0, 2 d IL-13 $0.48 \pm 0.06 \mathrm{p}<0.001,4$ d IL-13 $0.47 \pm 0.08 \mathrm{p}<$ $0.001,6 \mathrm{~d} \mathrm{IL}-130.57 \pm 0.10 \mathrm{p}<0.001$ ) (Figure 3A). There was no change in SP-A and SP-B mRNA levels.

We analyzed the protein level of proSP-C in the cell lysates by immunoblotting (Figure $2 \mathrm{~A}$ ) using $\mathrm{NIH}$ Image and examined proSP-C by immunofluorescence of the cultured cells (Figure 4A, B). The protein level of proSP-C in cell lysates from immunoblotting analysis measured by NIH Image was significantly decreased by IL-13 (relative increase of top band: $0.64 \pm 0.11 \mathrm{p}=$ $0.008,2^{\text {nd }}$ band: $0.31 \pm 0.12 \mathrm{p}<0.001,3^{\text {rd }}$ band: $0.21 \pm$ $0.04 \mathrm{p}<0.001$, bottom band: $0.22 \pm 0.07 \mathrm{p}<0.001$ ) (Figure 4A). In proportion to the protein expression of mature SP-C, the immunofluorescent level of proSP-C in the cells treated with IL-13 was markedly lower than cultures without IL-13 (Figure 4B top and middle pictures).

\section{Expression of surfactant proteins in adult human alveolar type II cells cultured on Matrigel and rat-tail collagen coated inserts with IFN- $\gamma$}

Human ATII cells were isolated and cultured in vitro for $8 \mathrm{~d}$ ( $2 \mathrm{~d}$ adherence, $2 \mathrm{~d}$ TGF $\alpha$ and $4 \mathrm{~d}$ KGF) with 100 $\mathrm{ng} / \mathrm{ml}$ human recombinant IFN- $\gamma$ for the last $4 \mathrm{~d}$ $(\mathrm{n}=6)$. We used $4 \mathrm{~d}$ of $100 \mathrm{ng} / \mathrm{ml}$ IFN- $\gamma$ for this experiment based on our previous experiments with the KIAD system (Additional File 1A right panel). The protein levels of surfactant proteins in the cell lysates were measured by immunoblotting (Figure 2A lane 3 and 7 and Figure $2 \mathrm{C}$ ). SP-A and mature SP-C protein levels were not changed by IFN- $\gamma$, whereas mature SP-B protein level was down-regulated (relative increase of mature SP-B: without IFN- $\gamma 1.0$, with IFN- $\gamma 0.55 \pm 0.09 \mathrm{p}<$ 0.001 ) and SP-D protein levels were significantly upregulated (relative increase of SP-D: without IFN- $\gamma 1.0$, with IFN- $\gamma 1.92 \pm 0.36 \mathrm{p}=0.028$ ) (Figure $2 \mathrm{~A}$ lane 3 and 7 , Figure $2 \mathrm{C}$ ). We then assessed the IFN- $\gamma$ effect on mRNA levels of surfactant proteins $(n=6)$. The mRNA levels of SP-A, $-\mathrm{C}$ and $-\mathrm{D}$ were increased by IFN- $\gamma$ (relative increase of SP-A: without IFN- $\gamma$ 1.0, with IFN- $\gamma$ $1.68 \pm 0.26 \mathrm{p}=0.024$, SP-C: $2.93 \pm 0.60 \mathrm{p}=0.009$, SPD: $2.87 \pm 0.28 \mathrm{p}<0.001)$ in response to $4 \mathrm{~d}$ of IFN- $\gamma$ stimulation (Figure 3B). There was no change in SP-B mRNA level.

We also analyzed protein level of proSP-C in the cell lysates by immunoblotting (Figure $2 \mathrm{~A}$ ) using NIH Image and examined proSP-C by immunofluorescence of the cultured cells (Figure 4A, B). The protein level of proSP-C in cell lysate from immunoblotting analysed by NIH Image was also greatly increased by IFN- $\gamma$ treatment (relative increase of top band: $2.86 \pm 0.52 \mathrm{p}=$ $0.005,2^{\text {nd }}$ band: $3.28 \pm 1.50 \mathrm{p}>0.05,3^{\text {rd }}$ band: $3.58 \pm$ $1.1 \mathrm{p}>0.05$, bottom band: $2.53 \pm 0.59 \mathrm{p}=0.040$ ) (Figure $4 \mathrm{~A})$. The immunofluorescent level of proSP-C in the cells cultured with IFN- $\gamma$ was remarkably higher than in cells without IFN- $\gamma$ (Figure 4B top and bottom pictures), and IFN- $\gamma$ treated cells possessed highly stained small dots in the cells, presumably membranous vesicles.

\section{Expression of cathepsin $\mathrm{H}$ and ATP binding cassette transporter A3 (ABCA3) in adult human ATII cells cultured with IL-13 or IFN- $\gamma$}

SP-B and SP-C are synthesized by ATII cell as proSP-B and proSP-C, which are proteolytically processed to mature SP-B and SP-C on route from its site of synthesis to the lamellar bodies [53,54]. Cathepsin $\mathrm{H}$ is one of the cysteine proteases involved in the processing of proSP-B and proSP-C. The first N-terminal processing step of proSP-C occurs in the electron-dense multivesicular bodies of ATII cells [53,54]. Because IFN- $\gamma$ decreased protein levels of mature SP-B without a change in SP-B mRNA, and significantly up-regulated SP-C mRNA and proSP-C protein without an increase in mature SP-C (Figure $2 \mathrm{C}, 3 \mathrm{~B}$ and $4 \mathrm{~A}$ ), we examined whether IFN- $\gamma$ changed the level of cathepsin $\mathrm{H}$ in ATII cells. The active form has a molecular size of $28 \mathrm{kDa}$ [55], and this band was reduced by IFN $\gamma$ but not by IL-13 (Figure 5A). However, there is no change in pepsinogen $C$ or napsin $A$, other proteases involved in the processing of proSP-C (data not shown).

ABCA3 is predominantly expressed in ATII cells and has been localized to the limiting membrane of lamellar bodies, which are the main intracellular storage organelle for pulmonary surfactant [56]. The protein expression of $\mathrm{ABCA} 3$ was measured by immunoblotting, and it was not altered by either IL-13 or IFN- $\gamma$ (Figure 5B), which suggests the effect of IL-13 and IFN- $\gamma$ primarily alter surfactant $B$ and $C$ processing and not lamellar body formation per se.

\section{Verification of these findings with other culture conditions in human ATII cells and results with rat ATII cells}

The results above were all done with adult human ATII cells cultured with $2 \mathrm{~d}$ of TGF $\alpha$ and $4 \mathrm{~d}$ of KGF. Similar findings were observed in ATII cells cultured in KGF (K) alone, in $2 \mathrm{~d}$ of $\mathrm{K}$ and $2 \mathrm{~d}$ of $\mathrm{KD}$ (data not shown) or in $2 \mathrm{~d}$ of KIA and $4 \mathrm{~d}$ of KIAD (Additional File 1A and $1 \mathrm{~B})$. The major difference was that in the untreated conditions, the $2 \mathrm{~d}$ of TGF $\alpha$ followed by $4 \mathrm{~d}$ of KGF showed slightly higher levels of mature SP-C, so that it was easier to demonstrate a decrease with IL-13. Additionally, the expression of mature SP-B was not altered in the KIA + KIAD system by IL-13 or IFN- $\gamma$ 


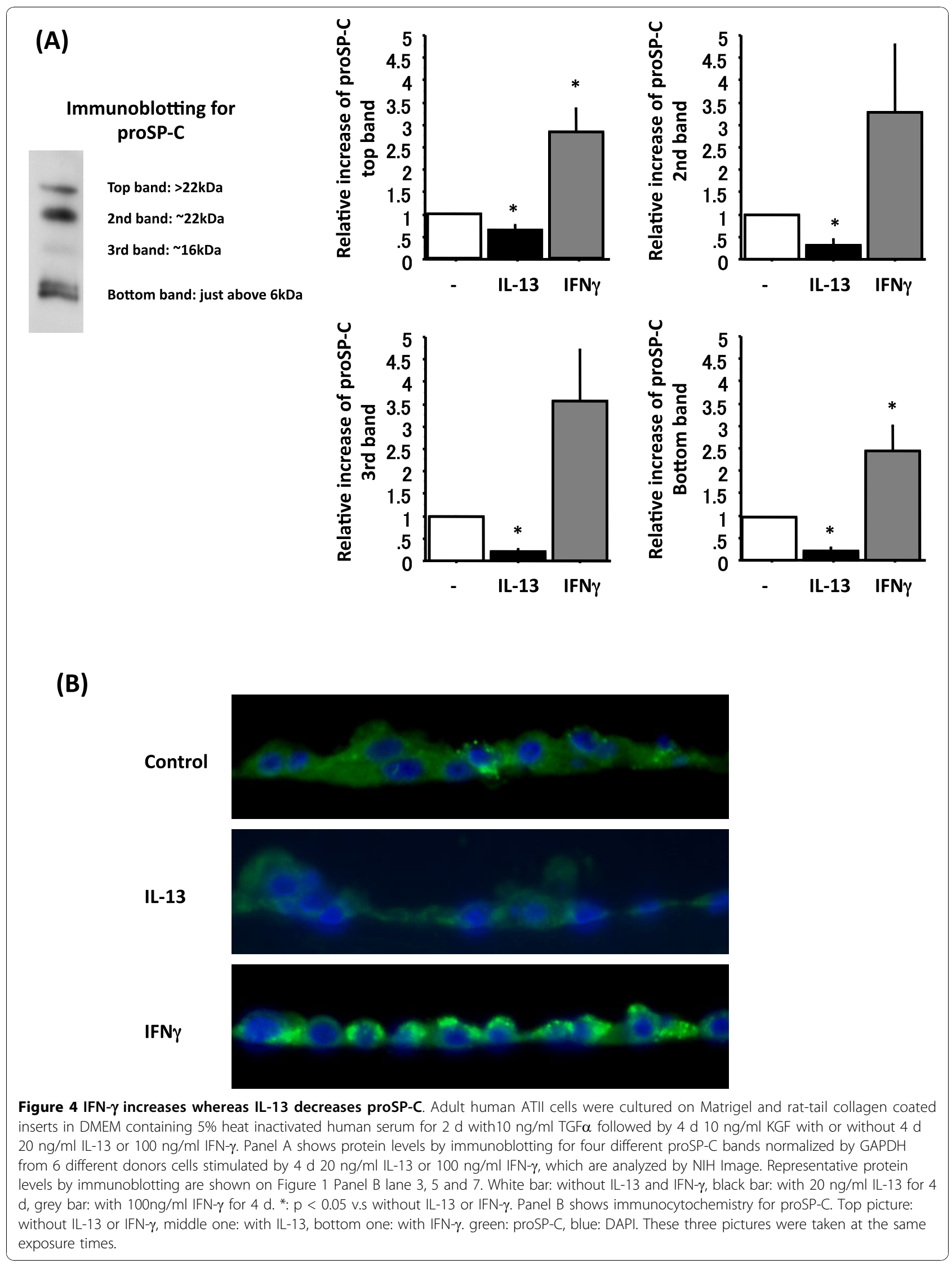




\section{(A)}

\section{5}

\section{CathepsinH}
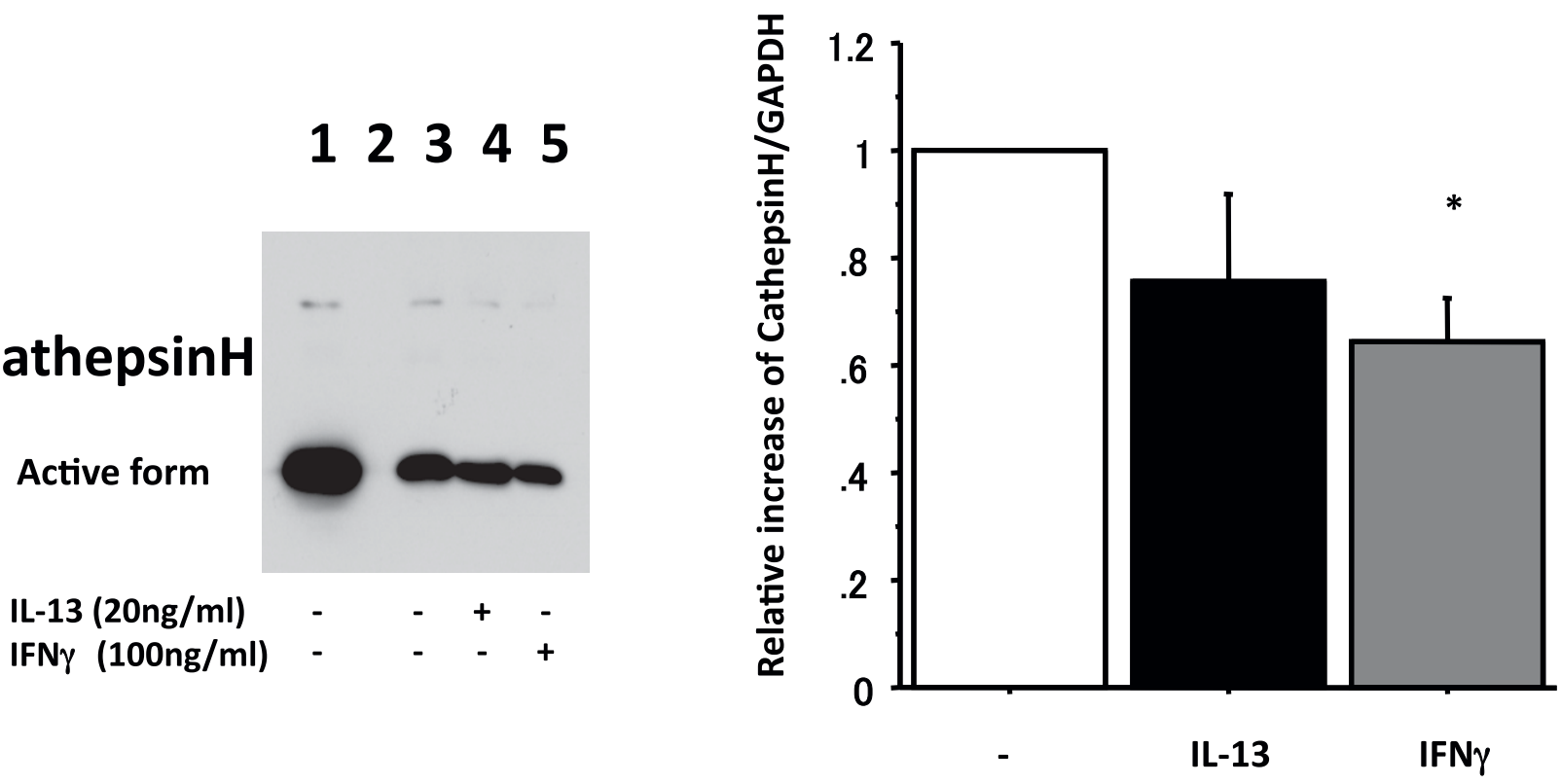

(B)

\section{5}

\section{ABCA3}

GAPDH
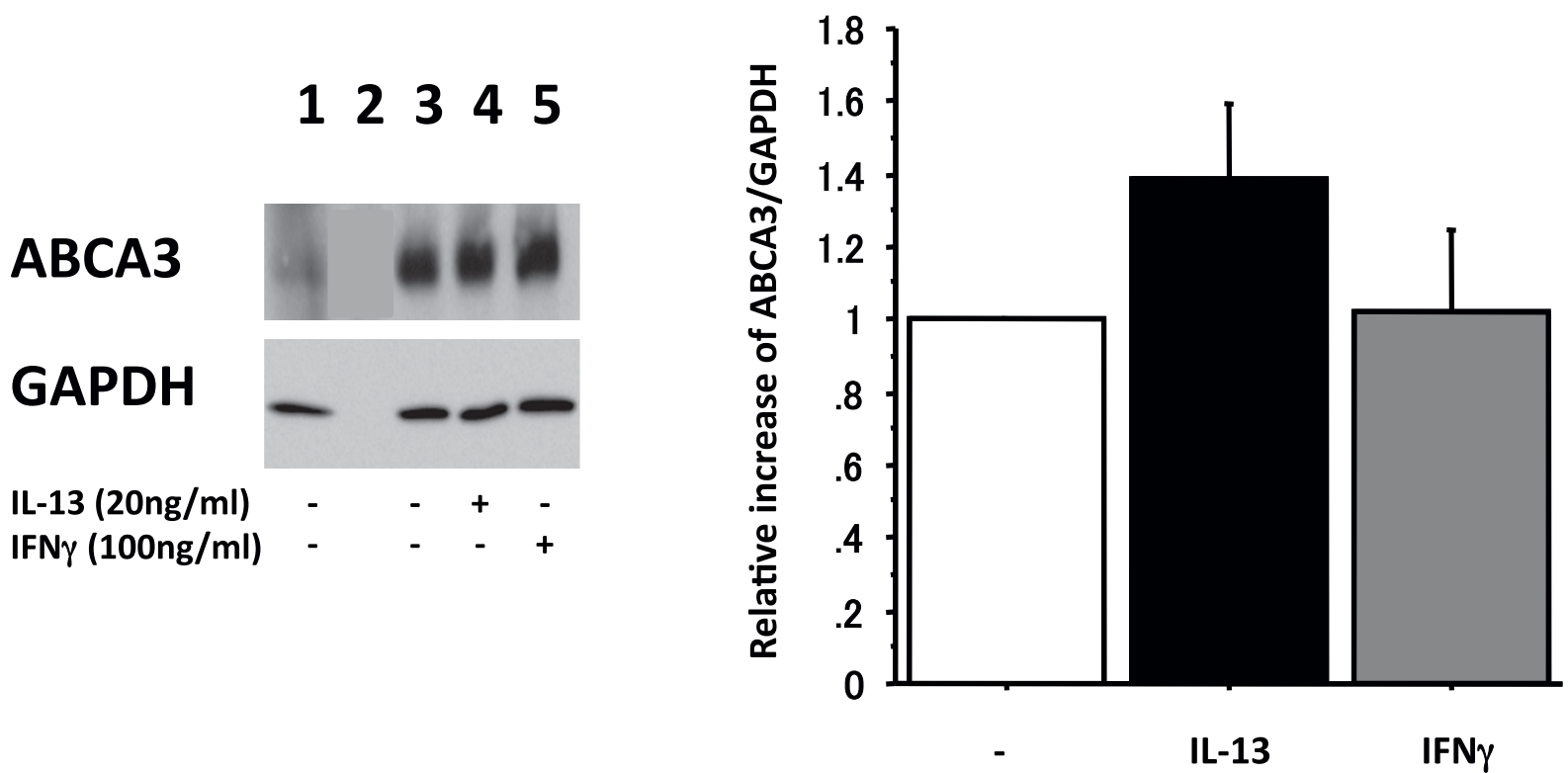

Figure 5 IFN- $\gamma$ reduces cathepsin $\mathbf{H}$ but not ABCA3. Adult human ATIl cells cultured on Matrigel and rat-tail collagen in DMEM containing $5 \%$ heat inactivated human serum with 2 d TGF $\alpha$ followed by 4 d KGF with $20 \mathrm{ng} / \mathrm{ml} \mathrm{IL-13} \mathrm{or} \mathrm{with} 100 \mathrm{ng} / \mathrm{ml}$ IFN- $\gamma$ for the final 4 days. Panel A shows representative active form of cathepsin $\mathrm{H}$ protein levels by immunoblotting and protein levels by immunoblotting for the active form cathepsin $\mathrm{H}$ normalized by GAPDH from 6 different donors, which are analyzed by NIH Image. Lane 1: day 0 control, Lane 2: empty, Lane 3: $2 \mathrm{~d}$ $10 \mathrm{ng} / \mathrm{ml} \mathrm{TGF} \alpha+4 \mathrm{~d} 10 \mathrm{ng} / \mathrm{ml} \mathrm{KGF}$, Lane 4: $2 \mathrm{~d} 10 \mathrm{ng} / \mathrm{ml} \mathrm{TGF} \alpha+4 \mathrm{~d} 10 \mathrm{ng} / \mathrm{ml} \mathrm{KGF}$ with $4 \mathrm{~d} 20 \mathrm{ng} / \mathrm{ml}$ IL-13, Lane 5: $2 \mathrm{~d} 10 \mathrm{ng} / \mathrm{ml} \mathrm{TGF} \alpha+4 \mathrm{~d}$ $10 \mathrm{ng} / \mathrm{ml} \mathrm{KGF}$ with $4 \mathrm{~d} 100 \mathrm{ng} / \mathrm{ml}$ IFN- $\gamma$. White bar: without IL-13 and IFN- $\gamma$, black bar: with $20 \mathrm{ng} / \mathrm{ml}$ IL-13 for 4 d, gray bar: with $100 \mathrm{ng} / \mathrm{ml}$ IFN$\gamma$ for 4 d. *: $p<0.05$ v.s. without IL-13 and IFN- $\gamma$. Panel B shows representative ABCA3 protein levels by immunoblotting and protein levels by immunoblotting for ABCA3 normalized by GAPDH from 6 different donors, which are analyzed by NIH Image. Lane order is same as in Panel A. White bar: without IL-13 and IFN- $\gamma$, black bar: with $20 \mathrm{ng} / \mathrm{ml}$ IL-13 for $4 \mathrm{~d}$, gray bar: with $100 \mathrm{ng} / \mathrm{ml}$ IFN- $\gamma$ for 4 d. *: $p<0.05$ v.s. without IL-13 and IFN- $\gamma$. 
(Additional File 1A, B, Additional File 2). In all conditions tested, IL-13 reduced the levels of proSP-C and mature SP-C and IFN- $\gamma$ increased the level of proSP-C. Hence, the effects of IL-13 and IFN $\gamma$ on SP-C did not depend on the differentiation factors that were used for the human ATII cells.

We cultured rat ATII for $6 \mathrm{~d}$ of KGF in DMEM including $5 \%$ RS with the last $4 \mathrm{~d}$ recombinant IL-13 or IFN- $\gamma$. The results from rat ATII cells were slightly different from the observations with human ATII cells. In rat ATII cells, IL-13 reduced expression of SP-A, mature SP-B, proSP-C and mature SP-C but not SP-D (Additional File 3A, B, Additional File 2). IFN- $\gamma$ increased SP-A, proSP-C and SP-D but not mature SP-C (Additional File 3A, B, Additional File 2). There was clearly incomplete processing of proSP-C, as indicated by the abundance of the $\sim 22 \mathrm{kDa}$ intermediate. The effects on proSP-C and mature SP-C by IL-13 and IFN- $\gamma$ were similar in rat and human ATII cells, whereas the effects on other surfactant proteins were not (Additional File 2).

\section{Discussion}

In this study, we showed that Th1/Th2 cytokines individually modulate the expression of surfactant proteins in adult human ATII cells. IL-13 reduced both mRNA and protein levels of SP-C and SP-D but did not alter those of SP-A and SP-B. Interestingly, IFN- $\gamma$ up-regulated the mRNA level of SP-C and protein level of proSP-C without an increase in mature SP-C. This indicates an alteration in the processing of proSP-C. These changes were accompanied by down-regulation of the active form of cathepsin $\mathrm{H}$, which is thought to be required for the processing of both proSP-B and proSP-C.

We used a different culture system for human type II cells from the one used in our previous report [48] and added TGF $\alpha$ to the culture system in this study. Maintenance of expression of both pro and mature SP-C is difficult with adult human ATII cells. Since SP-C levels were most significantly modified by IL-13 and IFN- $\gamma$ in this study, we tried several different combinations of additives including the KIAD system to increase the expression of mature SP-C. The changes in proSP-C by IL-13 and IFN- $\gamma$ were similar in all culture systems, but the expression of mature SP-C was low in the KIAD system. Therefore, we chose the culture system using 2 d $10 \mathrm{ng} / \mathrm{ml}$ TGF- $\alpha$ followed by $4 \mathrm{~d} 10 \mathrm{ng} / \mathrm{ml} \mathrm{KGF}$ in DMEM with $5 \%$ heat inactivated human serum, because this system was the best system for maintaining expression of mature SP-C (Figure 1A Lane 3 and 2A Lane 3).

The mechanism whereby IL-13 or IFN- $\gamma$ alters the expression of surfactant protein expression is not completely defined. However, alterations in surfactant protein levels can occur as a change in production, catabolism, processing (in terms of SP-B and SP-C) or a combination of several abnormalities. In this study, IL13 reduced both mRNA and protein levels of SP-C and SP-D in human adult ATII cells. Our results are different from previous reports in rodents, which show that IL-13-overexpression in mice increases SP-A, SP-B, SP$\mathrm{C}$ and SP-D [34] and that $4 \mathrm{~d}$ of $20 \mathrm{ng} / \mathrm{ml} \mathrm{IL-13}$ increases the intracellular SP-D protein level when compared to untreated cells in rat neonatal ATII cells in vitro [35]. We also performed similar experiments in vitro with rat adult ATII cells and found that rat IL-13 reduced the protein levels of SP-A, mature SP-B, proSP$\mathrm{C}$ and mature SP-C, and did not change that of SP-D (Additional File 3). Although the differences in the expression of surfactant proteins in response to IL-13 between with human and rat cells in vitro is most likely due to the species differences, it might also be due to the age of animals or the experimental systems. The differences among overexpressing mice, the human studies in vitro and rat studies in vitro is complicated because of the duration of exposure, the dose, compensatory mechanisms, and systemic effects as well as other confounding factors.

IL-13 has been known to play a pivotal role in the pathogenesis of lung disease such as asthma, IPF, viral pneumonia and COPD [22,28-33]. SP-D is an important component of innate immunity in the lungs [1]. Although it is difficult to explain the pathogenesis of lung diseases due to the dysregulation of only one cytokine, the down-regulation of SP-D in response to IL-13 might modify the pathogenesis of various diseases and may also alter the susceptibility to pathogens in patients with these diseases. IPF is proposed to result from multiple cycles of alveolar epithelial cell injury and activation instead of chronic inflammatory alveolitis [57]. IL-13 is found at elevated levels in the alveolar macrophages of IPF patients [30]. It has also been showed that human fibroblasts from patients with IPF are hyperresponsive to IL-13 [58]. Additionally, a high level of IL$13 R \alpha 2$ expression is detected in the lung epithelium, interstitium, and in mononuclear cells in surgical lung biopsies from patients with IPF [59]. IL-13 is elevated after administration of bleomycin in murine lungs and enhanced IL-13R $\alpha 2$ signaling is thought to be involved in bleomycin-induced lung fibrosis [60]. Moreover, some familial forms of pulmonary fibrosis are associated with mutations in the SP-C gene [7]. Increased and prolonged pulmonary fibrosis following intratracheal bleomycin injection is detected in SP-C -/- mice [21]. Our data reveal that SP-C expression in adult human ATII cells is reduced in response to IL-13. Taken together, it is possible that macrophages from patients with IPF produce IL-13, which decreases the expression of SP-C in ATII cells and initiates the development of IPF by producing alveolar instability, because SP-C helps lower 
the surface tension in the alveolar space. Importantly, anti-IL-13 therapeutic approaches to IPF (QAX576, Novartis, phase II clinical trial) have completed, and we await the results.

SP-B and SP-C are synthesized by ATII cells as proproteins (proSP-B and proSP-C) that are processed to mature SP-B and SP-C by serial cleavage of $\mathrm{NH}_{2}$ - and $\mathrm{COOH}$ - terminal peptides [53,54,61-63]. The first protease to be associated with proSP-B processing was cathepsin $\mathrm{H}[53,61]$ and inhibition of cathepsin $\mathrm{H}$ results in decreased production of mature SP-B. Napsin $A$ and pepsinogen $C$, asparatic proteases, are also involved in the processing of proSP-B $[53,63]$. We found no changes in the protein levels of napsin A or pepsinogen $\mathrm{C}$ with IL-13 or IFN- $\gamma$ in our studies (data not shown). On the other hand, the proteolytic processing of proSP-C to mature SP-C requires at least two distinct cleavages of the $\mathrm{C}$-terminal propeptide followed by at least two cleavages of the $\mathrm{N}$-terminal propeptide $[64,65]$. In the human lung, cathepsin $\mathrm{H}$ is involved in the first $\mathrm{N}$-terminal processing steps of proSP-C in the electron dense multivesicular bodies in ATII cells [54], but the proteases for cleavage of other sites are still unknown. Therefore, considering proSP-B processing steps, we postulate that the protein levels of mature SP-B are slightly reduced by IFN $-\gamma$ treatment in the TGF $\alpha+$ KGF system due to the reduction of the active form cathepesin $\mathrm{H}$. Similarly, the reduction in cathepsin $\mathrm{H}$, along with the increase in SP-C mRNA, produces a significant accumulation of proSP-C without an increase in mature SP-C. Zheng, T., et al. reported that IFN- $\gamma$ causes protease-antiprotease abnormalities [40], alveolar epithelial cell DNA injury and apoptosis via a cathepsin Sdependent pathway that leads to emphysema in the murine lung [37]. In the latter paper, IFN- $\gamma$ overexpression in mice resulted in an increase in cathepsin $\mathrm{H}$ mRNA levels, which appear inconsistent with our results. However, their experiment used mice, sustained overexpression of IL-13, and analyzed cathepsin H mRNA levels in the whole lung. Therefore there are many differences between their experiments and ours. Similarly, in terms of the expression of surfactant proteins in response to IFN- $\gamma$, our results differ from a previous report that showed in human fetal alveolar epithelial cells, IFN- $\gamma$ increased the SP-A protein level and mRNA levels, but did not affect SP-B and SP-C mRNA levels [41]. However, again there are many differences in experimental design that could account for the different results.

IFN- $\gamma$ production is stimulated by the innate immune response during infection, which alters macrophage function including enhanced pathogen recognition, antigen processing and presentation, stimulation of leukocyte recruitment, and activation of microbicidal effector functions and an anti-viral state [36]. In this study, we demonstrated that IFN- $\gamma$ induces SP-D expression in adult human ATII cells. Likewise, the dual function NADPH oxides/heme peroxidase (DUOX) 2 which is an inducible DUOX form in the human primary tracheobronchial epithelial cells and important for monitoring pathologic changes in the respiratory tract, is highly upregulated by IFN- $\gamma$, poly (I:C), or rhinovirus [66]. Considered together, it is suggested that IFN- $\gamma$ promotes the host defense mechanism not only in primary immune cells but also in respiratory epithelial cells.

ABCA3 is necessary for lamellar body biogenesis, SP-B processing, and lung development late in gestation [67]. ABCA3 deficiency in human and mice leads to decreased phosphatidylcholine and phosphatidylglycerol in surfactant, dysgenesis of lamellar bodies, and respiratory distress $[56,68]$. IL-13 and IFN- $\gamma$ alter SP-B, SP-C and cathepsin $\mathrm{H}$ expression diversely in our study. We thus hypothesized that these cytokines would alter lamellar body function. However, as shown in Figure 5B, $\mathrm{ABCA} 3$ expression was not changed by these cytokines. These results focus the effect of IL-13 and IFN- $\gamma$ on processing of SP-B and SP-C and not lamellar body genesis per se.

The results with rat cells were differed from the observations with human cells in several ways (Additional File 2). Therefore, it is important to confirm observations made with rodent cells with adult human cells, if the results with rodent cells are to be used to explain the pathogenesis of adult human lung diseases.

\section{Conclusions}

We demonstrate that IL-13 and IFN- $\gamma$ alter the expression of surfactant proteins in human adult ATII cells in vitro. Our current study suggests that these cytokines imbalance, that is Th1/Th2 cytokine imbalance, might contribute to the pathogenesis of lung diseases by disordering homeostasis in the alveolar space.

\section{Additional material}

Additional file 1: Effect of IL-13 and IFN- $\gamma$ on expression of surfactant proteins in adult human ATII cells cultured with a differentiation factors.

Additional File 2: Summary of the result from immunoblot data Additional File 3: IL-13 and IFN- $\gamma$ alter surfactant proteins expression in adult rat ATII cells.

\section{Acknowledgements}

We thank Karen E. Edeen for assistance with rat and human ATII isolation, and Jieru Wang, C. Joel Funk, Beata Kosmider, Emily Travanty, Mrinalini Nikrad and Jayashree Subramanian for assistance with human ATII cell isolations. Finally, we thank Teneke M. Warren and Catheryne Queen for assistance with manuscript preparation.

Declaration of all source of funding: This work was supported by a grant from the National Institutes of Health HL- 029891. 


\section{Authors' contributions}

YI carried out all human and rat ATIl cells studies. YI and RJM participated in the design of the study and data analysis. All authors have read and approved of the final manuscript.

\section{Competing interests}

The authors declare that they have no competing interests.

Received: 8 July 2010 Accepted: 10 November 2010 Published: 10 November 2010

\section{References}

1. Kuroki Y, Voelker DR: Pulmonary surfactant proteins. J Biol Chem 1994, 269:25943-25946.

2. Selman M, Lin HM, Montano M, Jenkins AL, Estrada A, Lin Z, Wang G, DiAngelo SL, Guo X, Umstead TM, et al: Surfactant protein A and B genetic variants predispose to idiopathic pulmonary fibrosis. Hum Genet 2003, 113:542-550.

3. Seifart $C$, Lin HM, Seifart U, Plagens A, DiAngelo $S$, von Wichert P, Floros J: Rare SP-A alleles and the SP-A1-6A(4) allele associate with risk for lung carcinoma. Clin Genet 2005, 68:128-136.

4. Seifart $C$, Seifart $U$, Plagens $A$, Wolf $M$, von Wichert P: Surfactant protein B gene variations enhance susceptibility to squamous cell carcinoma of the lung in German patients. Br J Cancer 2002, 87:212-217.

5. Lin Z, Pearson C, Chinchilli V, Pietschmann SM, Luo J, Pison U, Floros J: Polymorphisms of human SP-A, SP-B, and SP-D genes: association of SPB Thr131lle with ARDS. Clin Genet 2000, 58:181-191.

6. Guo X, Lin HM, Lin Z, Montano M, Sansores R, Wang G, DiAngelo S, Pardo A, Selman M, Floros J: Surfactant protein gene A, B, and D marker alleles in chronic obstructive pulmonary disease of a Mexican population. Eur Respir J 2001, 18:482-490.

7. Nogee LM, Dunbar AE, Wert SE, Askin F, Hamvas A, Whitsett JA: A mutation in the surfactant protein $C$ gene associated with familial interstitial lung disease. N Engl J Med 2001, 344:573-579.

8. Day AJ: The C-type carbohydrate recognition domain (CRD) superfamily. Biochem Soc Trans 1994, 22:83-88.

9. Kishore U, Bernal AL, Kamran MF, Saxena S, Singh M, Sarma PU, Madan T, Chakraborty T: Surfactant proteins SP-A and SP-D in human health and disease. Arch Immunol Ther Exp (Warsz) 2005, 53:399-417.

10. Wert SE, Yoshida M, LeVine AM, Ikegami M, Jones T, Ross GF, Fisher JH, Korfhagen TR, Whitsett JA: Increased metalloproteinase activity, oxidant production, and emphysema in surfactant protein $D$ gene-inactivated mice. Proc Natl Acad Sci USA 2000, 97:5972-5977.

11. LeVine AM, Whitsett JA, Gwozdz JA, Richardson TR, Fisher JH, Burhans MS, Korfhagen TR: Distinct effects of surfactant protein A or D deficiency during bacterial infection on the lung. J Immunol 2000, 165:3934-3940.

12. Schmidt R, Markart P, Ruppert C, Temmesfeld B, Nass R, Lohmeyer J, Seeger W, Gunther A: Pulmonary surfactant in patients with Pneumocystis pneumonia and acquired immunodeficiency syndrome. Crit Care Med 2006, 34:2370-2376.

13. Honda Y, Kuroki Y, Matsuura E, Nagae H, Takahashi H, Akino T, Abe S: Pulmonary surfactant protein $D$ in sera and bronchoalveolar lavage fluids. Am J Respir Crit Care Med 1995, 152:1860-1866.

14. Gunther A, Schmidt R, Nix F, Yabut-Perez M, Guth C, Rosseau S, Siebert C, Grimminger F, Morr H, Velcovsky HG, Seeger W: Surfactant abnormalities in idiopathic pulmonary fibrosis, hypersensitivity pneumonitis and sarcoidosis. Eur Respir J 1999, 14:565-573.

15. Noah TL, Murphy PC, Alink JJ, Leigh MW, Hull WM, Stahlman MT, Whitsett JA: Bronchoalveolar lavage fluid surfactant protein-A and surfactant protein-D are inversely related to inflammation in early cystic fibrosis. Am J Respir Crit Care Med 2003, 168:685-691.

16. van de Graaf EA, Jansen HM, Lutter R, Alberts C, Kobesen J, de Vries IJ, Out TA: Surfactant protein A in bronchoalveolar lavage fluid. I Lab Clin Med 1992, 120:252-263.

17. Cheng G, Ueda T, Numao T, Kuroki Y, Nakajima H, Fukushima Y, Motojima S, Fukuda T: Increased levels of surfactant protein $A$ and $D$ in bronchoalveolar lavage fluids in patients with bronchial asthma. Eur Respir J 2000, 16:831-835.

18. Honda Y, Takahashi H, Kuroki Y, Akino T, Abe S: Decreased contents of surfactant proteins A and D in BAL fluids of healthy smokers. Chest 1996, 109:1006-1009.
19. Betsuyaku T, Kuroki Y, Nagai K, Nasuhara Y, Nishimura M: Effects of ageing and smoking on SP-A and SP-D levels in bronchoalveolar lavage fluid. Eur Respir J 2004, 24:964-970.

20. Whitsett JA, Weaver TE: Hydrophobic surfactant proteins in lung function and disease. N Engl J Med 2002, 347:2141-2148.

21. Lawson WE, Polosukhin W, Stathopoulos GT, Zoia O, Han W, Lane KB, Li B, Donnelly EF, Holburn GE, Lewis KG, et al: Increased and prolonged pulmonary fibrosis in surfactant protein C-deficient mice following intratracheal bleomycin. Am J Pathol 2005, 167:1267-1277.

22. Wills-Karp M, Chiaramonte M: Interleukin-13 in asthma. Curr Opin Pulm Med 2003, 9:21-27.

23. Wills-Karp M, Luyimbazi J, Xu X, Schofield B, Neben TY, Karp CL, Donaldson DD: Interleukin-13: central mediator of allergic asthma. Science 1998, 282:2258-2261.

24. Grunig G, Warnock M, Wakil AE, Venkayya R, Brombacher F, Rennick DM, Sheppard D, Mohrs M, Donaldson DD, Locksley RM, Corry DB: Requirement for IL-13 independently of IL-4 in experimental asthma. Science 1998, 282:2261-2263

25. Zheng T, Zhu Z, Wang Z, Homer RJ, Ma B, Riese RJ Jr, Chapman HA Jr, Shapiro SD, Elias JA: Inducible targeting of IL-13 to the adult lung causes matrix metalloproteinase- and cathepsin-dependent emphysema. J Clin Invest 2000, 106:1081-1093.

26. Zhu Z, Homer RJ, Wang Z, Chen Q, Geba GP, Wang J, Zhang Y, Elias JA: Pulmonary expression of interleukin-13 causes inflammation, mucus hypersecretion, subepithelial fibrosis, physiologic abnormalities, and eotaxin production. J Clin Invest 1999, 103:779-788.

27. Zhu Z, Ma B, Zheng T, Homer RJ, Lee CG, Charo IF, Noble P, Elias JA: IL-13induced chemokine responses in the lung: role of CCR2 in the pathogenesis of IL-13-induced inflammation and remodeling. I Immunol 2002, 168:2953-2962.

28. Elias JA, Lee CG, Zheng T, Ma B, Homer RJ, Zhu Z: New insights into the pathogenesis of asthma. J Clin Invest 2003, 111:291-297.

29. Belperio JA, Dy M, Burdick MD, Xue YY, Li K, Elias JA, Keane MP: Interaction of $\mathrm{IL}-13$ and $\mathrm{C} 10$ in the pathogenesis of bleomycin-induced pulmonary fibrosis. Am J Respir Cell Mol Biol 2002, 27:419-427.

30. Hancock A, Armstrong L, Gama R, Millar A: Production of interleukin 13 by alveolar macrophages from normal and fibrotic lung. Am J Respir Cell Mol Biol 1998, 18:60-65.

31. Lukacs NW, Tekkanat KK, Berlin A, Hogaboam CM, Miller A, Evanoff H, Lincoln P, Maassab H: Respiratory syncytial virus predisposes mice to augmented allergic airway responses via IL-13-mediated mechanisms. J Immunol 2001, 167:1060-1065.

32. van der Pouw Kraan TC, Kucukaycan M, Bakker AM, Baggen JM, van der Zee JS, Dentener MA, Wouters EF, Verweij CL: Chronic obstructive pulmonary disease is associated with the $-1055 \mathrm{IL}-13$ promoter polymorphism. Genes Immun 2002, 3:436-439.

33. Bartalesi B, Cavarra E, Fineschi S, Lucattelli M, Lunghi B, Martorana PA, Lungarella G: Different lung responses to cigarette smoke in two strains of mice sensitive to oxidants. Eur Respir J 2005, 25:15-22.

34. Homer RJ, Zheng T, Chupp G, He S, Zhu Z, Chen Q, Ma B, Hite RD, Gobran LI, Rooney SA, Elias JA: Pulmonary type II cell hypertrophy and pulmonary lipoproteinosis are features of chronic IL-13 exposure. Am J Physiol Lung Cell Mol Physiol 2002, 283:L52-59.

35. Haczku A, Cao Y, Vass G, Kierstein S, Nath P, Atochina-Vasserman EN, Scanlon ST, Li L, Griswold DE, Chung KF, et al: IL-4 and IL-13 form a negative feedback circuit with surfactant protein-D in the allergic airway response. J Immunol 2006, 176:3557-3565.

36. Schroder K, Hertzog PJ, Ravasi T, Hume DA: Interferon-gamma: an overview of signals, mechanisms and functions. J Leukoc Biol 2004, 75:163-189.

37. Zheng T, Kang MJ, Crothers K, Zhu Z, Liu W, Lee CG, Rabach LA, Chapman HA, Homer RJ, Aldous D, et al: Role of cathepsin S-dependent epithelial cell apoptosis in IFN-gamma-induced alveolar remodeling and pulmonary emphysema. J Immunol 2005, 174:8106-8115.

38. Saetta M, Mariani M, Panina-Bordignon P. Turato G, Buonsanti C, Baraldo S, Bellettato CM, Papi A, Corbetta L, Zuin R, et al: Increased expression of the chemokine receptor $\mathrm{CXCR3}$ and its ligand $\mathrm{CXCL} 10$ in peripheral airways of smokers with chronic obstructive pulmonary disease. Am J Respir Crit Care Med 2002, 165:1404-1409.

39. Saetta M, Baraldo S, Corbino L, Turato G, Braccioni F, Rea F, Cavallesco G, Tropeano G, Mapp CE, Maestrelli P, et al: CD8+ve cells in the lungs of 
smokers with chronic obstructive pulmonary disease. Am J Respir Crit Care Med 1999, 160:711-717.

40. Wang Z, Zheng T, Zhu Z, Homer RJ, Riese RJ, Chapman HA Jr, Shapiro SD, Elias JA: Interferon gamma induction of pulmonary emphysema in the adult murine lung. J Exp Med 2000, 192:1587-1600.

41. Ballard PL, Liley HG, Gonzales LW, Odom MW, Ammann AJ, Benson B, White RT, Williams MC: Interferon-gamma and synthesis of surfactant components by cultured human fetal lung. Am J Respir Cell Mol Biol 1990, 2:137-143.

42. Ballard PL, Lee JW, Fang X, Chapin CJ, Allen L, Segal MR, Fischer H, Illek B, Gonzales LW, Kolla V, Matthay MA: Regulated gene expression in cultured type II cells of adult human lung. Am J Physiol Lung Cell Mol Physiol 2010, 299:L36-50.

43. Ware $L B$, Fang $X$, Matthay MA: Protein $C$ and thrombomodulin in human acute lung injury. Am J Physiol Lung Cell Mol Physiol 2003, 285:L514-521.

44. Fang X, Song Y, Hirsch J, Galietta $\sqcup$, Pedemonte N, Zemans RL, Dolganov G, Verkman AS, Matthay MA: Contribution of CFTR to apicalbasolateral fluid transport in cultured human alveolar epithelial type II cells. Am J Physiol Lung Cell Mol Physiol 2006, 290:L242-249.

45. Fuchs S, Hollins AJ, Laue M, Schaefer UF, Roemer K, Gumbleton M, Lehr CM: Differentiation of human alveolar epithelial cells in primary culture: morphological characterization and synthesis of caveolin-1 and surfactant protein-C. Cell Tissue Res 2003, 311:31-45.

46. Mason RJ, Apostolou S, Power J, Robinson P: Human alveolar type II cells: stimulation of DNA synthesis by insulin and endothelial cell growth supplement. Am J Respir Cell Mol Biol 1990, 3:571-577.

47. Witherden IR, Vanden Bon EJ, Goldstraw P, Ratcliffe C, Pastorino U, Tetley TD: Primary human alveolar type II epithelial cell chemokine release: effects of cigarette smoke and neutrophil elastase. Am J Respir Cell Mol Biol 2004, 30:500-509.

48. Wang J, Edeen $K$, Manzer R, Chang Y, Wang S, Chen X, Funk CJ, Cosgrove GP, Fang X, Mason RJ: Differentiated human alveolar epithelial cells and reversibility of their phenotype in vitro. Am J Respir Cell Mol Biol 2007, 36:661-668.

49. Mason RJ, Pan T, Edeen KE, Nielsen LD, Zhang F, Longphre M, Eckart MR, Neben S: Keratinocyte growth factor and the transcription factors C/EBP alpha, C/EBP delta, and SREBP-1c regulate fatty acid synthesis in alveolar type II cells. J Clin Invest 2003, 112:244-255.

50. Dobbs LG, Mason RJ: Pulmonary alveolar type II cells isolated from rats. Release of phosphatidylcholine in response to beta-adrenergic stimulation. J Clin Invest 1979, 63:378-387.

51. Krowczynska AM, Coutts M, Makrides S, Brawerman G: The mouse homologue of the human acidic ribosomal phosphoprotein PO: a highly conserved polypeptide that is under translational control. Nucleic Acids Res 1989, 17:6408.

52. Xu X, McCormick-Shannon K, Voelker DR, Mason RJ: KGF increases SP-A and SP-D mRNA levels and secretion in cultured rat alveolar type II cells. Am J Respir Cell Mol Biol 1998, 18:168-178.

53. Ueno $T$, Linder $S, N a C L$, Rice WR, Johansson J, Weaver TE: Processing of pulmonary surfactant protein B by napsin and cathepsin H. J Biol Chem 2004, 279:16178-16184

54. Brasch F, Ten Brinke A, Johnen G, Ochs M, Kapp N, Muller KM, Beers MF, Fehrenbach H, Richter J, Batenburg JJ, Buhling F: Involvement of cathepsin $\mathrm{H}$ in the processing of the hydrophobic surfactant-associated protein $\mathrm{C}$ in type II pneumocytes. Am J Respir Cell Mol Biol 2002, 26:659-670.

55. Woischnik M, Bauer A, Aboutaam R, Pamir A, Stanzel F, de Blic J, Griese M: Cathepsin $\mathrm{H}$ and napsin $\mathrm{A}$ are active in the alveoli and increased in alveolar proteinosis. Eur Respir J 2008, 31:1197-1204.

56. Brasch F, Schimanski S, Muhlfeld C, Barlage S, Langmann T, Aslanidis C, Boettcher A, Dada A, Schroten H, Mildenberger E, et al: Alteration of the pulmonary surfactant system in full-term infants with hereditary $A B C A 3$ deficiency. Am J Respir Crit Care Med 2006, 174:571-580.

57. Selman M, Pardo A: Role of epithelial cells in idiopathic pulmonary fibrosis: from innocent targets to serial killers. Proc Am Thorac Soc 2006, 3:364-372

58. Murray LA, Argentieri RL, Farrell FX, Bracht M, Sheng H, Whitaker B, Beck H, Tsui P, Cochlin K, Evanoff HL, et al: Hyper-responsiveness of IPF/UIP fibroblasts: interplay between TGFbeta1, IL-13 and CCL2. Int J Biochem Cell Biol 2008, 40:2174-2182.

59. Jakubzick C, Choi ES, Kunkel SL, Evanoff H, Martinez FJ, Puri RK, Flaherty KR, Toews GB, Colby TV, Kazerooni EA, et al: Augmented pulmonary IL-4 and
IL-13 receptor subunit expression in idiopathic interstitial pneumonia. J Clin Pathol 2004, 57:477-486.

60. Fichtner-Feigl S, Strober W, Kawakami K, Puri RK, Kitani A: IL-13 signaling through the IL-13alpha2 receptor is involved in induction of TGF-beta1 production and fibrosis. Nat Med 2006, 12:99-106.

61. Guttentag S, Robinson L, Zhang P, Brasch F, Buhling F, Beers M: Cysteine protease activity is required for surfactant protein $\mathrm{B}$ processing and lamellar body genesis. Am J Respir Cell Mol Biol 2003, 28:69-79.

62. Brasch F, Johnen G, Winn-Brasch A, Guttentag SH, Schmiedl A, Kapp N, Suzuki Y, Muller KM, Richter J, Hawgood S, Ochs M: Surfactant protein B in type II pneumocytes and intra-alveolar surfactant forms of human lungs. Am J Respir Cell Mol Biol 2004, 30:449-458.

63. Gerson KD, Foster CD, Zhang P, Zhang Z, Rosenblatt MM, Guttentag SH: Pepsinogen C proteolytic processing of surfactant protein B. J Biol Chem 2008, 283:10330-10338

64. Solarin KO, Ballard PL, Guttentag SH, Lomax CA, Beers MF: Expression and glucocorticoid regulation of surfactant protein $\mathrm{C}$ in human fetal lung. Pediatr Res 1997, 42:356-364.

65. Beers MF, Kim CY, Dodia C, Fisher AB: Localization, synthesis, and processing of surfactant protein SP-C in rat lung analyzed by epitopespecific antipeptide antibodies. J Biol Chem 1994, 269:20318-20328.

66. Harper RW, Xu C, Eiserich JP, Chen Y, Kao CY, Thai P, Setiadi H, Wu R: Differential regulation of dual NADPH oxidases/peroxidases, Duox1 and Duox2, by Th1 and Th2 cytokines in respiratory tract epithelium. FEBS Lett 2005, 579:4911-4917.

67. Cheong N, Zhang H, Madesh M, Zhao M, Yu K, Dodia C, Fisher AB, Savani RC, Shuman H: ABCA3 is critical for lamellar body biogenesis in vivo. J Biol Chem 2007, 282:23811-23817.

68. Fitzgerald ML, Xavier R, Haley KJ, Welti R, Goss JL, Brown CE, Zhuang DZ, Bell SA, Lu N, McKee $M$, et al: ABCA3 inactivation in mice causes respiratory failure, loss of pulmonary surfactant, and depletion of lung phosphatidylglycerol. J Lipid Res 2007, 48:621-632.

doi:10.1186/1465-9921-11-157

Cite this article as: Ito and Mason: The effect of interleukin-13 (IL-13) and interferon- $\gamma$ (IFN- $\gamma$ ) on expression of surfactant proteins in adult human alveolar type II cells in vitro. Respiratory Research 2010 11:157.

\section{Submit your next manuscript to BioMed Central and take full advantage of:}

- Convenient online submission

- Thorough peer review

- No space constraints or color figure charges

- Immediate publication on acceptance

- Inclusion in PubMed, CAS, Scopus and Google Scholar

- Research which is freely available for redistribution 